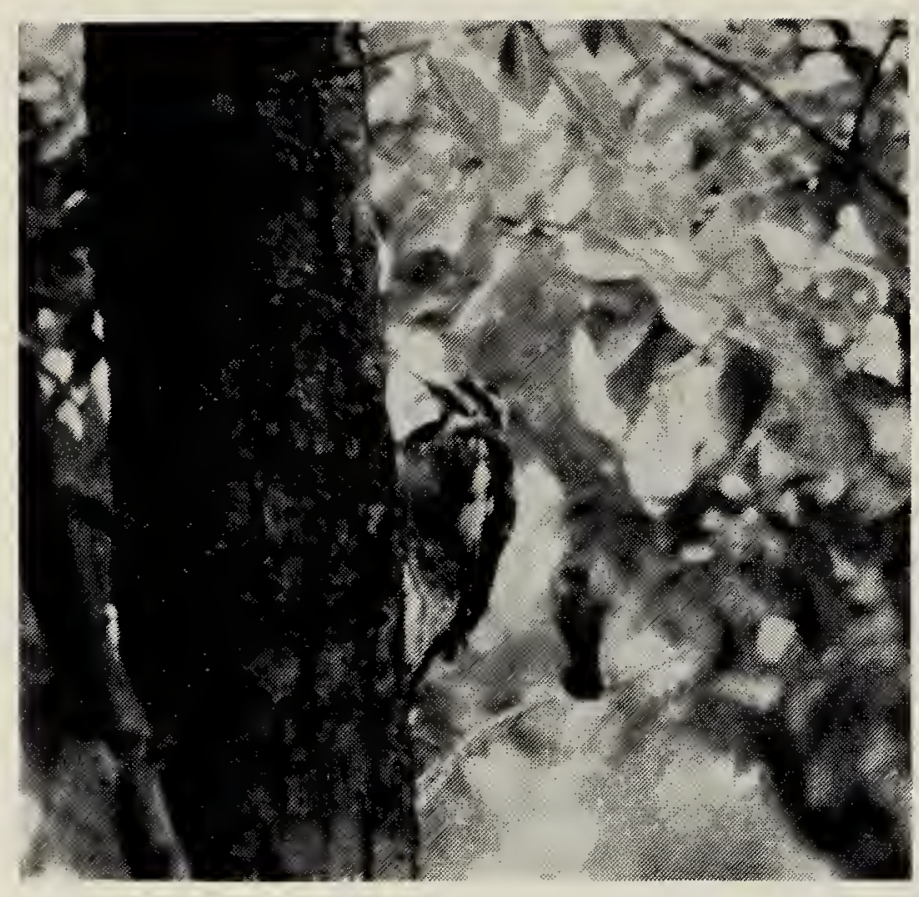

sapsucker would methodically move up the tree and every few minutes the hummingbird would return for more. I assume this behaviour is most prevalent in the fall when other food sources for the hummingbird have ceased flowering. - Christopher J. Escott, 271 Sylvian Way, Saskatoon, Saskatchewan. S7H 5G1

\section{ALBINOS AND MEMORIES OF GROUSE}

On 2 July 1984 I rode with David Watson of Swift Current to Stewart Valley and Riverhurst to see some fine Saskatchewan scenery. We headed south on \#644 as we wished to see all the wildlife we could. After travelling southward several miles and coming to the edge of a wide hollow, we saw a car parked by the roadside. The occupants were watching three fox kits romping around the mouth of their distant hillside den.

We saw one glistening albino with the two normal red ones; we were told that there had been another which was not so white, but it seemed timid and went below. I kept the sighting quiet then, for I feared if it were seen in print, many would try to see and shoot the albinos. I hope they have survived and by doing so give others the pleasure of the rare sighting we had.
Years ago, I saw a black and white, crow-shaped bird south of Birtle. It was one of an early spring flock of crows, and although colored a lot like a magpie, it acted very much like a crow. I have also seen a partial albino robin near my home in east end Brandon, and my late wife also saw it.

I am now in my 75th year of birdwatching, and as a lad not yet 5 (years old) I had the rare experience of poking bread crumbs from the ventilator holes where both Sharp-tailed and Pinnated grouse scrambled for them. My two older sisters and I got our fingers pecked if we were too slow withdrawing them. - Harold $E$. Watson, 220 Franklin Street, Brandon, Manitoba. R7A 5P3

\section{BIRD FEEDERS}

Just as the eastern sky begins to show a rosy glow, there is a distant stirring of chirps and softly whistled trills in the large poplar bluff around our house. Soon the flocks come closer, and the birds, one by one, glide or flutter down to the feeding trays located in front of the living-room windows. Lady Luck smiled our way this year - we've never hosted so many feathered guests before. Good sized flocks of Evening Grosbeaks, Pine Grosbeaks and redpolls come regularly to the feeders, keeping the resident birds company.

For a number of years, one of our most pleasant winter activities has been feeding and watching the birds a the feeding stations. Here, in the parkland area about $25 \mathrm{mi}$. north of the Qu'Appelle Valley, usually about a dozen chickadees and a pair each of Downy and Hairy woodpeckers seem to be yard residents the year around. These birds eagerly accept offerings of suet and their antics and cheery calls brighten many a frost day. The suet is hung from a tree branch so house sparrows can't steal it. 